\title{
Using AHP Method for Educational and Vocational Guidance
}

\author{
Essaid EL HAJI \\ Faculty of Sciences and Technologies, Department of Computer Science, Tangier, Morocco \\ E-mail: hessaid@ hotmail.fr \\ Abdellah Azmani ${ }^{1}$, Mohamed El Harzli ${ }^{2}$ \\ ${ }^{1}$ Faculty of Sciences and Technologies, Department of Computer Science, Tangier, Morocco \\ ${ }^{2}$ Faculty of Sciences and Technologies, Department of Electrical Engineering, Tangier, Morocco \\ E-mail: $\left\{{ }^{1}\right.$ abdellah.azmani@gmail.com, ${ }^{2}$ mohamed@elharzli.com\}
}

\begin{abstract}
This work focuses on the use of multi-criteria decision-making method AHP for using in educational and vocational guidance. Analytical Hierarchy Process (AHP), proposed by the mathematician Thomas Saaty in 1980 , is a method of analysis greatly used in the context of a multi-criteria analysis; it allows the comparison and the choice between the preset options. To achieve this goal, a vital work, preceded the use of the AHP method, which consists in doing a prototyping of trades according to the guidance criteria and sub-criteria. The IT system based on this method allows the student to find, firstly, the activities' sectors which are the most appropriate to his/her profile, to choose subsequently the trades and finally, to identify, the potential training paths.
\end{abstract}

Index Terms-Educational and Vocational Guidance, AHP, multi-criteria analysis, RIASEC, Big 5.

\section{INTRODUCTION}

The advent and rapid evolution of information and communications technologies (ICT) have paved the way toward the development of a multitude of tools for educational use. These tools have greatly contributed to not only improving the quality of education but also in covering the shortfall and therefore representing an alternative: e-learning and guidance assisted by the computer are two testimonies.

In fact, Guichard and Hutteau [1] do not see any advantage of the in-class guidance compared to that based on the use of the computer tool. In addition, others [2-4] advocate that the guidance based on IT presents various advantages: Free or less expensive in relation to a consultation with a specialist, more interactive, promoting the autonomy, Etc.

This awareness has given a great boost to the development of software to aid in educational and vocational guidance; however, it does not exist up to now a global and universal doctrine of guidance. This limits the role of the intervention of these IT tools.

In this paper, we use the AHP method in order to implement a system for educational and vocational guidance, which allows a student to build his/her professional project in four steps.

\section{A. Step 1: choice of activities' sectors}

In this step, we propose a set of activities' sectors (education, teaching, Medicine, nature, etc.) the most suitable (appropriate) to the student profile, based on a set of criteria.

\section{B. Step 2: choice of trades}

In general, each sector includes a wide range of professions, for example in the field of medicine; there are the trades: doctor, pediatrician, pharmacist, midwife, etc.). Other criteria are taken into account in this step, such as educational data because each trade requires special training. In this step, the system proposes a set of trades that are the most appropriate to the student profile.

\section{Step 3, choice of training}

Depending on the trades selected in the previous step, the systemoffers the possible training for such a job.

\section{Step 4, Choice of training path}

Often the same training is accessible via several different paths. For a student, choosing a training path is dictated by several factors of pedagogical nature (notes, skills, abilities, etc.), socio-economic (social class, job of parents, etc.), cultural and even religious nature in some societies.

The process is referred to in the Figure 3.

\section{ThE ANALYTICAL HiERARCHY PROCESS}

This paragraph is content to present an outline of the AHP method by focusing on the different stages of this process.

\section{A. General presentation}

AHP (Analytical hierarchy process), proposed by Saaty [5] is one of the strongest and the most used methods in the context of multi-criteria analysis [6]. It is based on the decomposition of a complex problem of decision into criteria and on the synthesis and aggregation of weight 
associated with the different criteria for different levels of the hierarchy. The preferences between criteria are expressed by the weight $\mathrm{w}_{\mathrm{j}}$ from comparison matrix by pair between criteria with the same level of the hierarchy according to a scale of ration semantics [6].

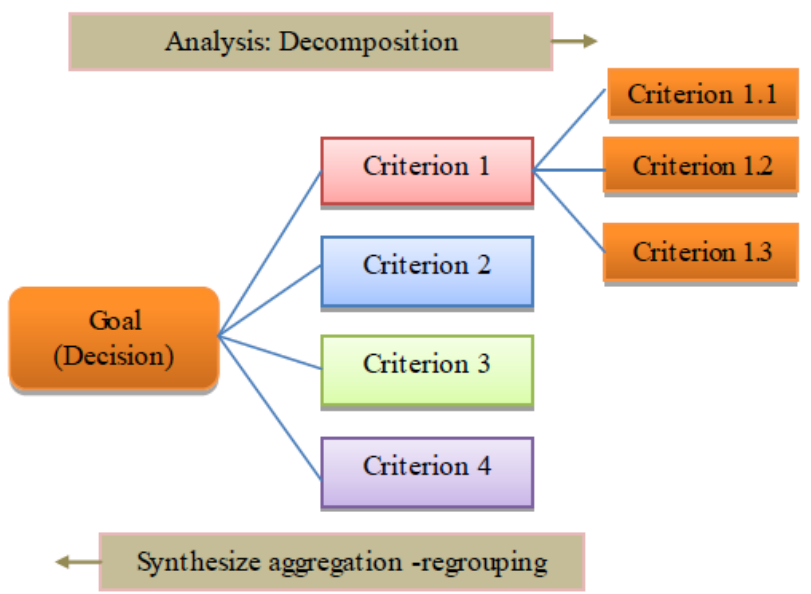

Fig.1.An analysis process AHP

\section{B. Steps of an AHP analysis [7-9]:}

An AHP analysis is decomposed into following steps:

- The hierarchical structuring of the problem: The first phase of each AHP analysis is to structure the decision problem into criteria and sub-criteria in the form of a graph (figure1).

- Construction of a matrix of judgment: It is often difficult for policy makers to associate with precision the weight corresponding to the different attributes. AHP helps to determine the values for each attribute using the judgments of decision makers or data based on a standard scale. These weights are stored in a matrix called pairwise comparis on matrix (or matrix of judgment). The judgments are expressed in cardinal values and each $a_{i j}$ judgment indicates how much the attribute ' $i$ ' is more important than the attribute ' $\mathrm{j}$ '.

$$
A=\left(\begin{array}{ccc}
a_{11} & \ldots & a_{1 n} \\
\vdots & \ddots & \vdots \\
a_{n 1} & \cdots & a_{n n}
\end{array}\right)
$$

The judgment matrix is a square matrix A having $n$ attribute whose relative weights are $\mathrm{w}_{1}, \mathrm{w}_{2} \ldots \mathrm{w}_{\mathrm{n}}$. The weights of the attributes are measured with respect to each other according to the equation 2 .

$$
a_{i j}=\frac{w_{i}}{w_{j}} \forall i, j=1,2, \ldots, \mathrm{p}
$$

\section{Study of the consistency of the matrix of judgment}

The consistency of checking the choice of the weights is to detect the inconsistency and, if necessary, to correct the affected weight. For this, we calculate a vector of 
consistency CR, with:

$$
C R=\frac{C I}{R I}
$$

Where $\mathrm{CI}$ is the indicator of consistency that is given by the equation 5, and RI: "Random Index" is a number function of $\mathrm{n}$, indicated in tables ad hoc.

Table 4. Array of indices RI

\begin{tabular}{|c|c|c|c|c|c|c|c|c|}
\hline $\mathbf{n}$ & 3 & 4 & 5 & 6 & 7 & 8 & 9 & 10 \\
\hline $\mathbf{R I}$ & 0,58 & 0,90 & 1,12 & 1,24 & 1,32 & 1,41 & 1,45 & 1,49 \\
\hline
\end{tabular}

$$
C I=\frac{\lambda_{\max }-n}{n-1}
$$

Where $\mathrm{n}$ is the number of elements to compare (rank of the matrix of preferences)

$$
\lambda_{\max }=\sum_{i, j}^{n}\left(\frac{C_{i j} \cdot W_{j}}{W_{j}}\right)
$$

Where $C_{i j}$ are the elements of the matrix of judgment and $\mathrm{W}_{\mathrm{j}}$ the elements of the weight vector.

If $\mathrm{CR}>0.1$, we need to review the judgments expressed through the weights of the matrix of preferences.

\section{E. Comparative study of alternatives to choose the best}

In this step, we calculate the relative importance of the alternatives in relation to the indicators of each criterion and a matrix of preference is calculated, (we) obtain the vector of the relative importance of the alternatives in relation to each criterion.

Once the vectors of the relative importance of the alternatives in relation to the indicators are determined, we move on to the calculation of relative importance of the alternatives with regard, this time, to the criteria and, then, to calculate this importance in relation to the objective.

\section{USING AHP METHOD FOR EDUCATIONAL AND VOCATIONAL GUIDANCE}

This section presents our approach of using the AHP method in the field of educational and vocational guidance. It presents an illustrative example by means of a sample case study.

\section{A. The guidance is a problem of multi-criteria analysis}

The educational and vocational guidance is a process that makes an appeal to several factors. In fact, the choice of guidance is often based on several criteria. Several studies have examined the demographic factors and personal which may influence the choice of professional and educational guidance. Among the personal factors, the level of general ability (10), culture or cultural status
(11), values and principles (12), self-esteem (13) selfefficacy (14), interests (14), personality [15] are decisive factors in the choice of the vocational and educational guidance of pupils. Among the demographic factors, the work of the parent (16), the level of study of the parents (17), ethnic origins (11), as well as the socioeconomic status, gender, and age of the student (10). These criteria do not have the same importance with respect to the different trades, i.e. the importance of a criterion varies according to each trade.

The use of the AHP method will allow us to structure the diffe rent criteria and to determine the importance of a criterion with respect to each other.

\section{B. Use of the AHP method}

- Prototyping of Trades: The prototyping trades step is a crucial and very important step in our work. It is to categorize the different trades depending on the set of criteria likely to intervene in the process of guidance. In fact, it is so rare and hard to find an expert capable, by himself, to make this categorization, because we are facing a situation where the data originated from several sources and fuzzy kind. To alleviate this problem we will use an original method which made calls to methods of treatment of the imperfect information and it is based on the notion of multi-expertise. This work will be developed in another article.

Prototyping of trades is done according to the principle proposed in the following figure:

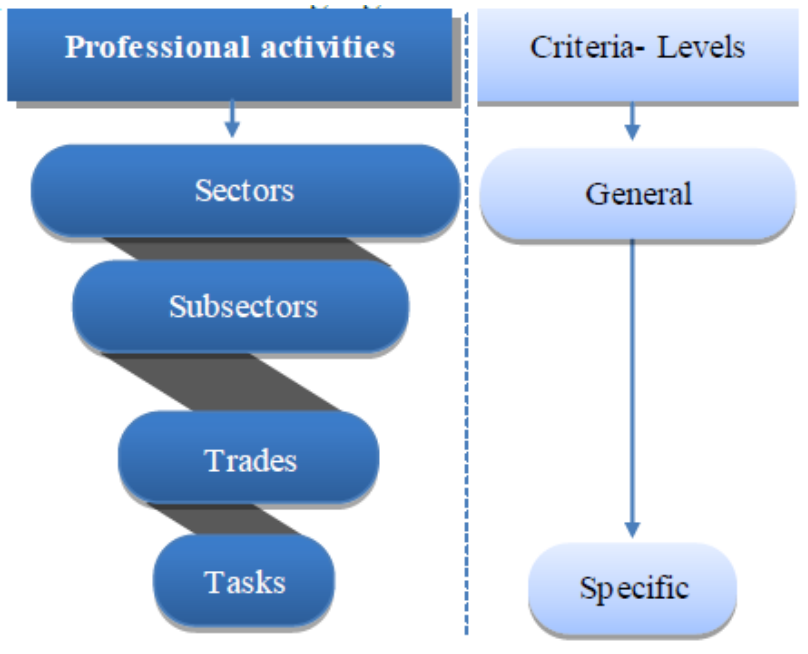

Fig.2. prototyping process of trades

- Proposed process: We propose a funnel guidance model which helps the student to gradually define his/her guidance project. The model used to generate, respectively, the sectors of activity, trades, training and training paths. For each level of the model, a set of criteria are taken into account and the student may have the option of stopping at any level or go to the end of the process. This flexibility allows the student to use the system in different stages of his/her school and academic career. 
This model allows the student to find, firstly, the activities' sectors which are the most appropriate to his/her profile, to choose subsequently the trades and finally, to identify the potentialtraining paths.

The choice of a training path is very important for both students and parents because choosing a suitable path can avoid many problems, such as unnecessary displacements (travels) and expenses.

This model is briefly presented in the following Figure (Fig.3)

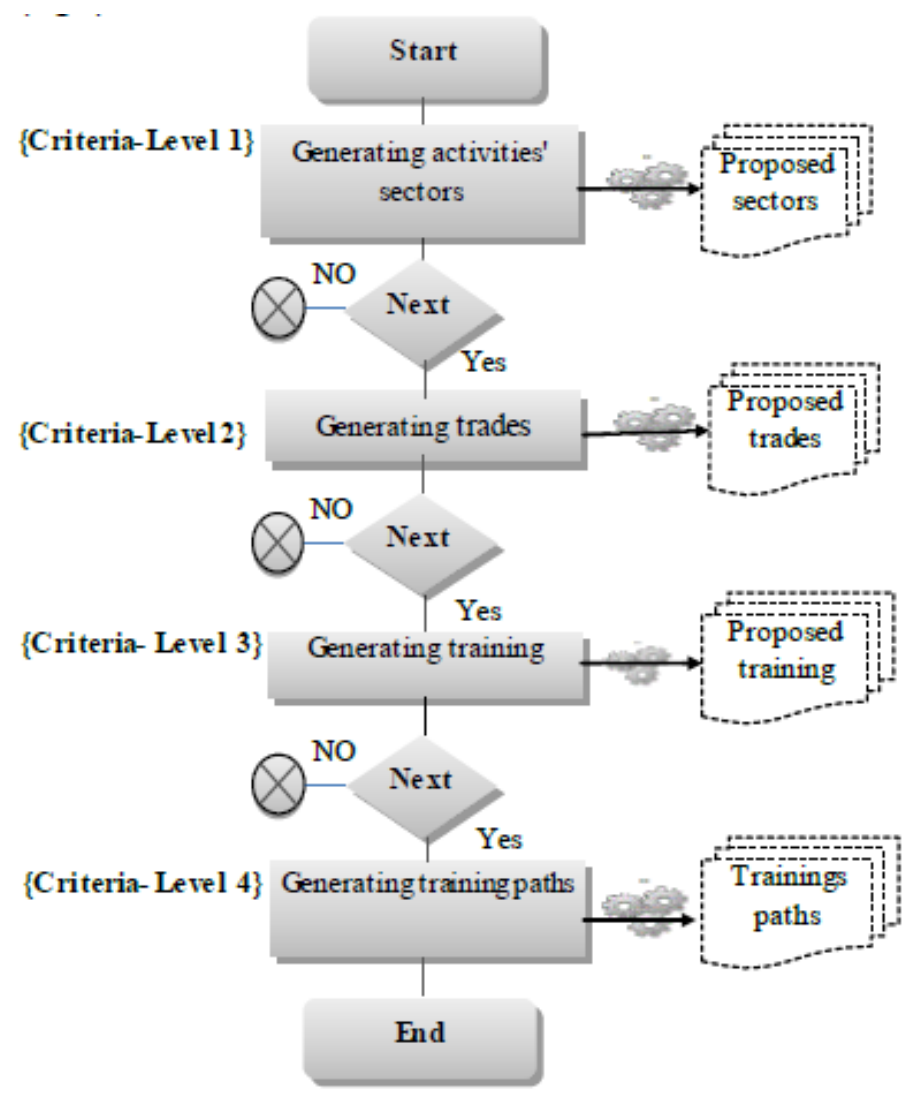

Fig.3. The proposed process to generate a guidance project

\section{Case Study}

Table 5. Criteria and sub criteria of the present study

\begin{tabular}{|c|c|c|}
\hline Criteria & Indicators & Definition \\
\hline & $\mathrm{R}$ & Realistic \\
Professional & $\mathrm{I}$ & Investigator \\
Interests & $\mathrm{A}$ & Artist \\
From Holland & $\mathrm{S}$ & Social \\
& $\mathrm{C}$ & Entrepreneur \\
& $\mathrm{C}$ & Conventional \\
\hline & $\mathrm{HM}$ & Education and Teaching \\
& $\mathrm{AG}$ & Health and Medicine \\
Sub-interests & $\mathrm{NE}$ & Agriculture \\
& $\mathrm{Op}$ & Oture and Environment \\
\hline & $\mathrm{Co}$ & Consciencieusite \\
& $\mathrm{Ex}$ & Extraversion \\
Personality & $\mathrm{Ag}$ & Agreeability \\
Traits & $\mathrm{Ne}$ & Neuroticisme \\
& \multicolumn{2}{|c}{} \\
\hline
\end{tabular}

In this case study, we present an example while remaining in step I in our model. It, therefore, seeks; using AHP analysis, proposing to the concerned student the sector(s) of activities the most appropriate to his/her profile. To do this, we use the criteria: Professional Interests (PI) of Holland translated by the code RIASEC,
Personality Traits (PT) depending on the model Big 5 and the Sub-interests of the student. The criteria and indicators are reported in the following table:

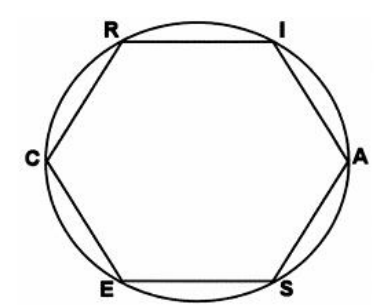

Fig.4. Circular representation of Holland RIASEC model

- Professional interests from Holland: Holland (1966) proposed a theory of "vocational choice", distinguishing six categories of professional interests (Realistic, Investigative, Artistic, Social, Enterprising, and Conventional), corresponding to different personality profiles. This classification is used to describe people, environ ments, and their interactions; it also serves to establish a typology of "Vocation choice" which explains "the vocational choice" of an individual. Holland has shown this typology with a 
hexagonal pattern defining the psychological resemblances and interactions between personality types and environments [18], [19], [20].

- Personality Traits according to Big 5: Big 5 is currently considered as one of the most popular models for the analysis of personality [21 in 22] According to this model, five major areas of the personality: Nerveucisme, extraversion, openness, friendliness, and conscience are used to explain individual differences in the evaluations of Personality [22]. This evaluation model is today used as well for the question of recruitment than that of vocational training.

- Sub-interests: At a vocational choice, the wishes expressed by an individual must be respected as much as possible because it is so discouraged that someone has a job that he does not like. Therefore, the sub-interests are to be taken into consideration in the guidance process. In this case study, the subinterests are simply the areas of activities preferred by the individual and we have chosen the following sectors: Education and Teaching, Health \& Medicine, Agriculture, Nature \& Environment.
- Education and Teaching: Teacher, Professor, Educator, Guidance Counselor, etc.

- Health and Medicine: Doctor, Nurse, Psychologist, Social Assistant, etc.

- Nature and Environment: Environmental Advisor, Gardener, Eng ineer in protection of the environment, Geologist, Farmer, etc.

The case study concerns one individual whose

- The RIASEC code is SAICER

- The personality traits according to the method Big 5 are opening, Agreeability, extraversion, Conscience and Neuroticis me

- The chosen areas according to the order of its preferences: Education and Teaching (ET), Health \& Medicine (HM), Agriculture (AG) Nature \& Environment (NE).

D. AHP process

a) Structuring of problem

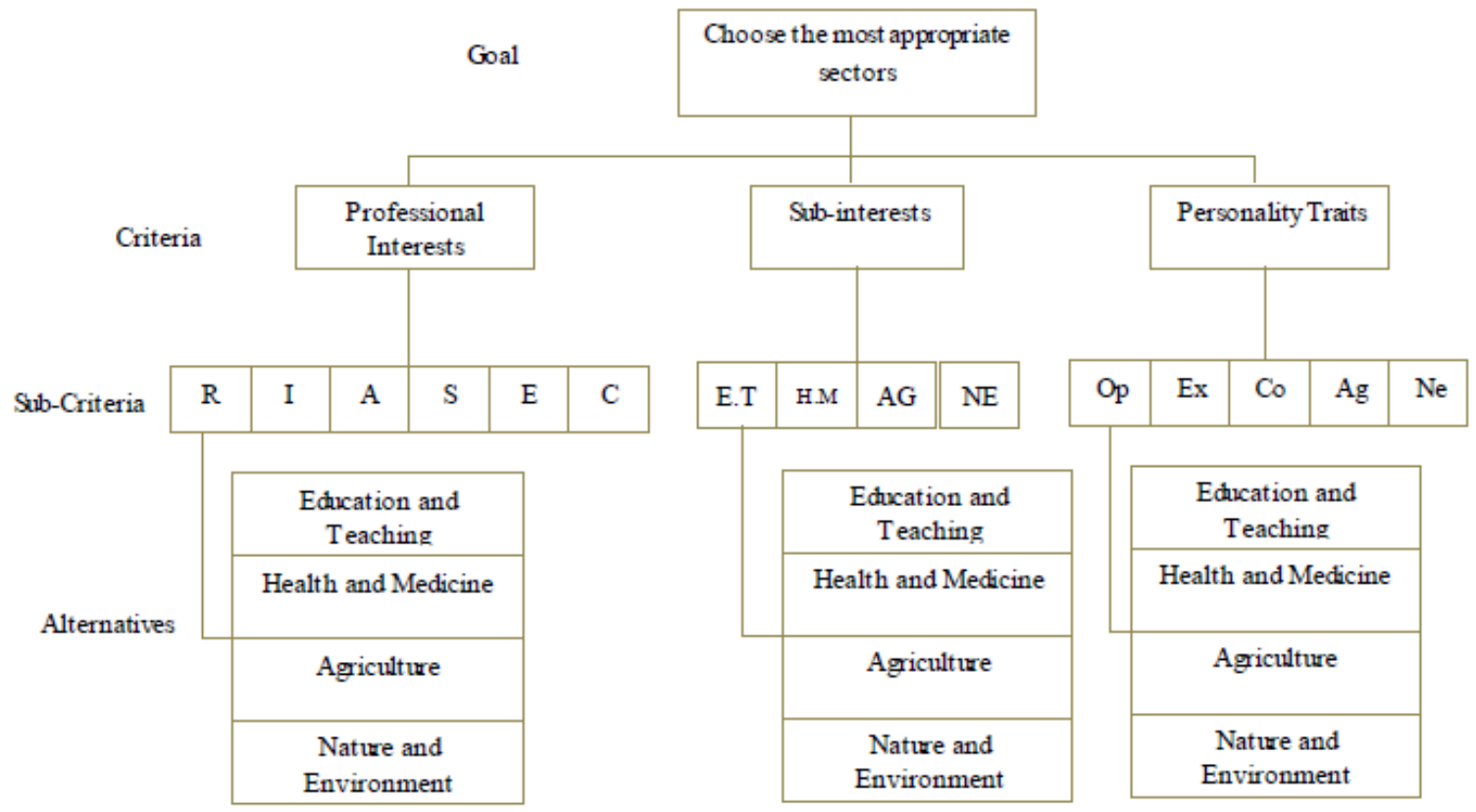

Fig.5. AHP structuring the case study

b) Processing and results

Matrix of the judgment of the first level (level criteria)

Table 6. The judgment matrix of the first level

\begin{tabular}{|c|c|c|c|c|}
\hline & $\begin{array}{c}\text { Professional } \\
\text { Interests }\end{array}$ & $\begin{array}{c}\text { Sub- } \\
\text { interests }\end{array}$ & $\begin{array}{c}\text { Personality } \\
\text { Traits }\end{array}$ & $\mathrm{W}$ \\
\hline $\begin{array}{c}\text { Professional } \\
\text { Interests }\end{array}$ & 0.65 & 0.69 & 0.56 & 0.63 \\
\hline Sub-interests & 0.22 & 0.23 & 0.33 & 0.26 \\
\hline $\begin{array}{c}\text { Personality } \\
\text { Traits }\end{array}$ & 0.13 & 0.08 & 0.11 & 0.11 \\
\hline
\end{tabular}

Relative Importance and standardized weight at the level of indicators (sub-criteria)

Table 7. Relative importance of indicators RIASEC

\begin{tabular}{|c|c|c|c|c|c|c|c|}
\hline $\mathrm{IP}$ & $\mathrm{R}$ & $\mathrm{I}$ & $\mathrm{A}$ & $\mathrm{S}$ & $\mathrm{E}$ & $\mathrm{C}$ & $\mathrm{W}$ \\
\hline $\mathrm{R}$ & 0.04 & 0.02 & 0.03 & 0.06 & 0.02 & 0.01 & 0.03 \\
\hline $\mathrm{I}$ & 0.18 & 0.10 & 0.07 & 0.11 & 0.18 & 0.20 & 0.14 \\
\hline $\mathrm{A}$ & 0.25 & 0.31 & 0.21 & 0.18 & 0.30 & 0.28 & 0.25 \\
\hline $\mathrm{S}$ & 0.32 & 0.51 & 0.62 & 0.53 & 0.42 & 0.36 & 0.46 \\
\hline $\mathrm{E}$ & 0.11 & 0.03 & 0.04 & 0.08 & 0.06 & 0.12 & 0.07 \\
\hline $\mathrm{C}$ & 0.11 & 0.02 & 0.03 & 0.06 & 0.01 & 0.04 & 0.04 \\
\hline
\end{tabular}


Table 8. Relative importance of indicators Sub-interests

\begin{tabular}{|c|c|c|c|c|c|}
\hline Sub-interests & ET & HM & AG & NE & W \\
\hline ET & 0.60 & 0.66 & 0.54 & 0.44 & 0.56 \\
\hline HM & 0.20 & 0.22 & 0.32 & 0.31 & 0.26 \\
\hline AG & 0.12 & 0.07 & 0.11 & 0.19 & 0.12 \\
\hline NE & 0.09 & 0.04 & 0.04 & 0.06 & 0.06 \\
\hline
\end{tabular}

Table 9. Relative importance of indicators personality traits

\begin{tabular}{|c|c|c|c|c|c|c|}
\hline $\mathrm{TP}$ & $\mathrm{Ou}$ & $\mathrm{Ex}$ & $\mathrm{Ne}$ & $\mathrm{Ag}$ & $\mathrm{Co}$ & $\mathrm{W}$ \\
\hline $\mathrm{Ou}$ & 0.22 & 0.32 & 0.31 & 0.19 & 0.31 & 0.27 \\
\hline $\mathrm{Ex}$ & 0.07 & 0.11 & 0.22 & 0.11 & 0.18 & 0.14 \\
\hline $\mathrm{Ne}$ & 0.03 & 0.02 & 0.04 & 0.06 & 0.02 & 0.04 \\
\hline $\mathrm{Ag}$ & 0.65 & 0.53 & 0.40 & 0.56 & 0.43 & 0.51 \\
\hline $\mathrm{Co}$ & 0.03 & 0.02 & 0.01 & 0.08 & 0.06 & 0.04 \\
\hline
\end{tabular}

Weight local, global, and each indicator

Table 10. Weight global and each indicator

\begin{tabular}{|c|c|c|c|}
\hline Criterion & \multirow{2}{*}{ Sub-criterion } & \multicolumn{2}{|c|}{ weight } \\
\hline \multirow[b]{2}{*}{$\begin{array}{c}\text { Pr. Int } \\
\text { weight } \\
\mathbf{0 . 6 3}\end{array}$} & & local & global \\
\hline & $\begin{array}{l}\mathrm{R} \\
\mathrm{I} \\
\mathrm{A} \\
\mathrm{S} \\
\mathrm{E} \\
\mathrm{C}\end{array}$ & $\begin{array}{l}0.03 \\
0.14 \\
0.25 \\
0.46 \\
0.07 \\
0.04\end{array}$ & $\begin{array}{l}0.0189 \\
0.0882 \\
0.1575 \\
0.2898 \\
0.0441 \\
0.0252\end{array}$ \\
\hline Criterion & \multirow{2}{*}{ Sub-criterion } & \multicolumn{2}{|c|}{ weight } \\
\hline \multirow[b]{2}{*}{$\begin{array}{l}\text { Sub-interests } \\
\text { weight } \\
\mathbf{0 . 2 6}\end{array}$} & & local & global \\
\hline & $\begin{array}{c}\text { ET } \\
\text { HM } \\
\text { AG } \\
\text { NE }\end{array}$ & $\begin{array}{l}0.56 \\
0.26 \\
0.12 \\
0.06\end{array}$ & $\begin{array}{l}0.1456 \\
0.0676 \\
0.0312 \\
0.0156\end{array}$ \\
\hline Criterion & \multirow{2}{*}{ Sub-criterion } & \multicolumn{2}{|c|}{ weight } \\
\hline & & local & global \\
\hline $\begin{array}{l}\text { Traits. Per } \\
\text { weight } \mathbf{0 . 1 1}\end{array}$ & $\begin{array}{l}\mathrm{Op} \\
\mathrm{Ex} \\
\mathrm{Ag} \\
\mathrm{Ne} \\
\mathrm{Co}\end{array}$ & $\begin{array}{l}0.27 \\
0.14 \\
0.04 \\
0.51 \\
0.04\end{array}$ & $\begin{array}{l}0.0264 \\
0.0154 \\
0.0044 \\
0.0561 \\
0.0044\end{array}$ \\
\hline
\end{tabular}

Relative degree of success in the performance of indicators by each functional unit

Table 11. Relative degree of success of professional interests' indicators

\begin{tabular}{|c|c|c|c|c|c|}
\hline \multicolumn{7}{|c|}{ Criterion Realistic (R) } \\
\hline $\mathbf{R}$ & ET & HM & AG & NE & W \\
\hline ET & 0.10 & 0.10 & 0.06 & 0.25 & 0.13 \\
\hline HM & 0.10 & 0.10 & 0.06 & 0.25 & 0.13 \\
\hline AG & 0.70 & 0.70 & 0.44 & 0.25 & 0.52 \\
\hline NE & 0.10 & 0.10 & 0.44 & 0.25 & 0.22 \\
\hline \multicolumn{7}{|c|}{ Criterion Investigator (I) } \\
\hline I & EE & SM & AG & NE & W \\
\hline ET & 0.10 & 0.13 & 0.35 & 0.05 & 0.16 \\
\hline HM & 0.50 & 0.65 & 0.35 & 0.77 & 0.57 \\
\hline AG & 0.10 & 0.09 & 0.05 & 0.03 & 0.07 \\
\hline
\end{tabular}

\begin{tabular}{|c|c|c|c|c|c|}
\hline $\mathrm{NE}$ & 0.30 & 0.13 & 0.25 & 0.15 & 0.21 \\
\hline \multicolumn{6}{|c|}{ Criterion Artist (A) } \\
\hline A & ET & HM & AG & NE & $\mathrm{W}$ \\
\hline ET & 0.44 & 0.44 & 0.44 & 0.44 & 0.44 \\
\hline $\mathrm{HM}$ & 0.44 & 0.44 & 0.44 & 0.44 & 0.44 \\
\hline $\mathrm{AG}$ & 0.06 & 0.06 & 0.06 & 0.06 & 0.06 \\
\hline NE & 0.06 & 0.06 & 0.06 & 0.06 & 0.06 \\
\hline \multicolumn{6}{|c|}{ Criterion Social (S) } \\
\hline S & ET & HM & AG & $\mathrm{NE}$ & $\mathrm{W}$ \\
\hline ET & 0.42 & 0.42 & 0.36 & 0.41 & 0.40 \\
\hline HM & 0.42 & 0.42 & 0.36 & 0.41 & 0.40 \\
\hline $\mathrm{AG}$ & 0.08 & 0.08 & 0.07 & 0.05 & 0.07 \\
\hline $\mathrm{NE}$ & 0.08 & 0.08 & 0.21 & 0.14 & 0.13 \\
\hline \multicolumn{6}{|c|}{ Criterion Entrepreneur (E) } \\
\hline $\mathrm{E}$ & ET & HM & AG & NE & $\mathrm{W}$ \\
\hline ET & 0.30 & 0.30 & 0.30 & 0.30 & 0.30 \\
\hline HM & 0.10 & 0.10 & 0.10 & 0.10 & 0.10 \\
\hline AG & 0.30 & 0.30 & 0.30 & 0.30 & 0.30 \\
\hline NE & 0.30 & 0.30 & 0.30 & 0.30 & 0.30 \\
\hline \multicolumn{6}{|c|}{ Criterion Conventional (C) } \\
\hline $\mathrm{C}$ & ET & $\mathrm{HM}$ & $\mathrm{AG}$ & $\mathrm{NE}$ & W \\
\hline ET & 0.25 & 0.25 & 0.25 & 0.25 & 0.25 \\
\hline $\mathrm{HM}$ & 0.25 & 0.25 & 0.25 & 0.25 & 0.25 \\
\hline AG & 0.25 & 0.25 & 0.25 & 0.25 & 0.25 \\
\hline $\mathrm{NE}$ & 0.25 & 0.25 & 0.25 & 0.25 & 0.25 \\
\hline
\end{tabular}

Table 12. Relative degree of success of sub-interests' indicators

\begin{tabular}{|c|c|c|c|c|c|}
\hline \multicolumn{7}{|c|}{ Criterion Education and Teaching (ET) } \\
\hline ET & EE & HM & AG & NE & W \\
\hline ET & 0.62 & 0.05 & 0.50 & 0.50 & 0.42 \\
\hline HM & 0.21 & 0.05 & 0.36 & 0.36 & 0.24 \\
\hline AG & 0.09 & 0.45 & 0.07 & 0.07 & 0.17 \\
\hline NE & 0.09 & 0.45 & 0.07 & 0.07 & 0.17 \\
\hline \multicolumn{7}{|c|}{ Criterion Health and Medicine (HM) } \\
\hline HM & ET & HM & AG & NE & W \\
\hline ET & ET & 0.11 & 0.21 & 0.36 & 0.36 \\
\hline HM & HM & 0.33 & 0.62 & 0.50 & 0.50 \\
\hline AG & AG & 0.54 & 0.09 & 0.07 & 0.07 \\
\hline NE & NE & 0.02 & 0.09 & 0.07 & 0.07 \\
\hline \multicolumn{7}{|c|}{ Criterion Agriculture (AG) } \\
\hline AG & ET & HM & AG & NE & W \\
\hline ET & 0.05 & 0.05 & 0.07 & 0.03 & 0.05 \\
\hline HM & 0.05 & 0.05 & 0.09 & 0.03 & 0.05 \\
\hline AG & 0.45 & 0.45 & 0.63 & 0.71 & 0.56 \\
\hline NE & 0.45 & 0.45 & 0.21 & 0.24 & 0.34 \\
\hline \multicolumn{7}{|c|}{ Criterion Nature and En vironment (NE) } \\
\hline NE & ET & HM & AG & NE & W \\
\hline ET & ET & 0.06 & 0.06 & 0.03 & 0.07 \\
\hline HM & HM & 0.06 & 0.06 & 0.03 & 0.07 \\
\hline AG & AG & 0.39 & 0.39 & 0.23 & 0.21 \\
\hline NE & 9 & 9 & 3 & 1 & 0.59 \\
\hline
\end{tabular}


Table 13. Relative degree of success of personality traits' indicators

\begin{tabular}{|c|c|c|c|c|c|}
\hline \multicolumn{7}{|c|}{ Criterion openness (Op) } \\
\hline Op & ET & HM & AG & NE & W \\
\hline ET & 0.43 & 0.38 & 0.44 & 0.44 & 0.42 \\
\hline HM & 0.14 & 0.13 & 0.11 & 0.11 & 0.12 \\
\hline AG & 0.21 & 0.25 & 0.22 & 0.22 & 0.23 \\
\hline NE & 0.21 & 0.25 & 0.22 & 0.22 & 0.23 \\
\hline \multicolumn{7}{|c|}{ Criterion Extraversion (Ex) } \\
\hline Ex & ET & HM & AG & NE & W \\
\hline ET & 0.42 & 0.42 & 0.42 & 0.42 & 0.42 \\
\hline HM & 0.42 & 0.42 & 0.42 & 0.42 & 0.42 \\
\hline AG & 0.08 & 0.08 & 0.08 & 0.08 & 0.08 \\
\hline NE & 0.08 & 0.08 & 0.08 & 0.08 & 0.08 \\
\hline \multicolumn{7}{|c|}{ Criterion Nerveucisme (Ne) } \\
\hline Ne & ET & HM & AG & NE & W \\
\hline ET & 0.38 & 0.38 & 0.38 & 0.38 & 0.38 \\
\hline
\end{tabular}

\begin{tabular}{|c|c|c|c|c|c|}
\hline HM & 0.38 & 0.38 & 0.38 & 0.38 & 0.38 \\
\hline AG & 0.13 & 0.13 & 0.13 & 0.13 & 0.13 \\
\hline NE & 0.13 & 0.13 & 0.13 & 0.13 & 0.13 \\
\hline \multicolumn{7}{|c|}{ Criterion Agre eability (Ag) } \\
\hline Ag & ET & HM & AG & NE & W \\
\hline ET & 0.42 & 0.42 & 0.42 & 0.42 & 0.42 \\
\hline HM & 0.42 & 0.42 & 0.42 & 0.42 & 0.42 \\
\hline AG & 0.08 & 0.08 & 0.08 & 0.08 & 0.08 \\
\hline NE & 0.08 & 0.08 & 0.08 & 0.08 & 0.08 \\
\hline \multicolumn{7}{|c|}{ Criterion Consciencieusite (Co) } \\
\hline Co & ET & HM & AG & NE & W \\
\hline ET & 0.46 & 0.55 & 0.38 & 0.38 & 0.44 \\
\hline HM & 0.23 & 0.27 & 0.38 & 0.38 & 0.31 \\
\hline AG & 0.15 & 0.09 & 0.13 & 0.13 & 0.12 \\
\hline NE & 0.15 & 0.09 & 0.13 & 0.13 & 0.12 \\
\hline
\end{tabular}

Partial contribution of each functional unit to the overall performance objective

Table 14. Partial contribution of each functional unit to the overall performance objective

\begin{tabular}{|c|c|c|c|c|c|c|c|c|c|c|c|}
\hline Prof .Interests & Ind R & Ind I & Ind A & Ind S & IndE & Ind C & & Indicator & & Result & \\
\hline Edu.Tch & 0.13 & 0.16 & 0.44 & 0.40 & 0.30 & 0.25 & \multirow{5}{*}{$X$} & $\mathbf{R} 0.0189$ & & Edu.Tch & 0.22 \\
\hline Hea.Med & 0.13 & 0.57 & 0.44 & 0.40 & 0.10 & 0.25 & & I 0.0882 & & Hea. Med & 0.25 \\
\hline Agr & 0.52 & 0.07 & 0.06 & 0.07 & 0.30 & 0.25 & & A 0.1575 & $=$ & Agr & 0.07 \\
\hline \multirow[t]{2}{*}{ Nat.Env } & 0.22 & 0.21 & 0.06 & 0.13 & 0.30 & 0.25 & & $\begin{array}{ll}\text { S } & 0.2898 \\
\mathbf{E} & 0.0441 \\
\mathbf{C} & 0.0252\end{array}$ & & Nat.Env & 0.09 \\
\hline & & & & & & & & & & $\mathbf{W}=$ & 0.63 \\
\hline
\end{tabular}

\begin{tabular}{lcrllllll}
\hline Sub-interests & Ind. ET & Ind. HM & Ind. AG & Ind. NE & Indicator & Result \\
\hline Edu.Tch & $\mathbf{0 . 4 2}$ & 0.26 & 0.05 & 0.38 & & ET 0.1456 & Edu.Tch & 0.09 \\
Hea.Med & $\mathbf{0 . 2 4}$ & 0.49 & 0.05 & 0.38 & HM 0.0676 & Hea.Med & 0.08 \\
Agr & $\mathbf{0 . 1 7}$ & 0.19 & 0.56 & 0.13 & AG 0.0312 & Agr & 0.06 \\
Nat.Env & $\mathbf{0 . 1 7}$ & 0.06 & 0.34 & 0.13 & & NE 0.0156 & Nat.Env & 0.04 \\
& & & & & & & W= & $\mathbf{0 . 2 7}$ \\
\hline
\end{tabular}

\begin{tabular}{|c|c|c|c|c|c|c|c|c|c|c|}
\hline Personality Traits & IndOp & IndAg & IndEx & IndCo & Ind Ne & & Indicat or & & $\overline{R e s u l t}$ & \\
\hline Edu.Tch & 0.42 & 0.42 & 0.42 & 0.44 & 0.38 & & Op 0.0264 & & Edu.Tch (ET) & 0.04 \\
\hline Hea.Med & 0.12 & 0.42 & 0.42 & 0.31 & 0.38 & & Ag 0.0044 & & Hea.Med(HM) & 0.03 \\
\hline Agr & 0.23 & 0.08 & 0.08 & 0.12 & 0.13 & $\mathrm{X}$ & Ex 0.0154 & $=$ & $\operatorname{Agr}(\mathrm{AG})$ & 0.02 \\
\hline \multirow[t]{2}{*}{ Nat.Env } & 0.23 & 0.08 & 0.08 & 0.12 & 0.13 & & Co 0.0044 & & Nat.Env (NE) & 0.02 \\
\hline & & & & & & & & & $W=$ & 0.11 \\
\hline
\end{tabular}

Final results for assessment of the best performing functional unit.

Table 15. Final results for assessment of the best performing functional unit.

\begin{tabular}{lllll}
\hline & Prof. Int & Traits.pers & Sub-interests & Total \\
\hline Education and Teaching & 0.22 & 0.09 & 0.04 & 0.35 \\
Health and Medicine & 0.25 & 0.08 & 0.03 & 0.36 \\
Agriculture & 0.07 & 0.06 & 0.02 & 0.15 \\
Nature et environnement & 0.09 & 0.04 & 0.02 & 0.15 \\
Total & 0.63 & 0.27 & 0.11 & 1.00 \\
\hline
\end{tabular}


In the light of the obtained results, we can say that the profile of the individual is closest to the areas Health \& medicine the first choice, followed by Education \& Teaching the second position, while the other two remaining areas : Agriculture and Nature \& Environment are relatively far with regard to the profile of the individual.

\section{CONCLUSION AND PROSPECTS}

In this paper, the multi-criteria decision-making method AHP is used for educational and vocational guidance. Although the results obtained show how interesting is this method, it appears unable to deal with the fuzzy nature of the used data. In fact, and as a logical continuation of this work, we aim to complete it using the FAHP method that will allow us to process the fuzzy nature of manipulated data.

\section{REFERENCES}

[1] J. Guichard and M. Hutteau, "Psychologie de l'orientation," 2006

[2] F. Rivas, "Tecnología informática en asesoramiento vocacional, Psicothema," 2005

[3] S.A.I.O. - Rectorat de Versailles, "Les logiciels d'aide à l'orientation," 2007.

[4] R. Chappat, "L'informatique comme aide à l'orientation," LE BULLETIN DE L'EPI N ${ }^{\circ} 65$.

[5] T. Saaty, "The analytic hierarchy process," McGraw Hill, New York, 1980.

[6] J.M. TACNET, M. Batton-Hube and J. Deze, "Multicriteria decision analysis and information fusion for expertise applied to natural risks in mountains," Colloque LambdaMu 17 -5-7, La Rochelle, France, Octobre 2010.

[7] T. Saaty, "Some mathematical concepts of the analytic hierarchy process," Behaviormetrika 29, 1-9, 1991.

[8] Fouzia Ounnar, Selma Khader, Yves Dubromelle, JeanPierre, Prunaret, Patrick Pujo, “ Évaluation d'une méthode d'ordonnancement multicritère utilisant AHP,"

[9] Noorami and all, "Comparison of AHP and FAHP for Selecting Yard Gantry Cranes in Marine Container Terminals," Journal of the Persian Gulf (Marine Science)/Vol. 3/No. 7, 59-70, March 2012

[10] S. Davies and N. Guppy, "Fields of study, college selectivity, and student inequalities in higher education," Social Forces, 75 (4), 1417-1438, 1997.

[11] J. C. Simpson, "Segregated by subject: racial differences in the factors influencing academic major between European Americans, Asian Americans, and African, Hispanic, and native Americans, "Journal of Higher Education, 72(1), 63-100, 2001.

[12] K.M. Galotti and Making "a Major real-life decision: college students choosing an academic major," Journal of Educational Psychology, 91(2), 379-387, 1999.

[13] C. A. Coperthwaite, "The effect of self-esteem, locus of control, and background factors on college students' choice of an academic major," Unpublished doctoral dissertation, The University of Connecticut, Connecticut, USA, 1994.

[14] N. E. Betz, and P. J. Rottinghaus, Current research on parallel measures of interests and confidence for basic dimensions of vocational activity," Journal of Career Assessment, 14(1), 56-76, 2006.

[15] J. W. Lounsbury, R. M. Smith, J. J. Levy, F. T. Leon and
L. W. Gibson, "Personality characteristics of business majors as de fined by the Big Five and narrow personality traits, " Journal of Education for Business, 84(4), 200206, 2009.

[16] K. Leppel, "Race, Hispanic ethnicity, and the future of the college business major in the United Sates," Journal of Education for Business, 76(4), 209-215, 2001.

[17] N. C. Ware, N. A. Steckler, and J. Leserman, "Undergraduate woman: who chooses a science major?," Journal of Higher Education, 56(1), 73-84, 1985.

[18] Guglielmi, F. Fraccaroli and M. L. Pombeni, "The Professional Interests According to Holland's Hexagonal Model Structures and Gender Difference, " OSP, 33/3|2004, p. 409-427, 2004

[19] B. Stevanovic and N. Mosconi, “ Les représentations des métiers des adolescent(e-s) scolarisé(e-s) dans l'enseignement secondaire, " Revue française de pédagogie [En ligne], 161 | octobre-décembre 2007.

[20] M. Lisa Larson, J. Patrick Rottinghaus, and F. H. Borgen, "Meta-analy ses of Big Six Interests and Big Five Personality Factors, "Journal of Vocational Behavior 61, 217-239 (2002).

[21] L. R. Goldberg, "An alternative description of personality: The Big-Five factor structure," Journal of Personality and Social Psychology, 59, 1216-1229, 1990.

[22] M. Ziegler, D. Bensch, U. Maaß, V. Schult, M. Vogel and M. Bühner, "Big Five facets as predictor of job training performance: The role of specific job demands", Learning and individual Differences 29 1-7, (2014)

[23] Essaid, E., Abdellah, A., \& Mohamed, E. A funnel model for educational and vocational guidance in using AHP method, 3rd GLOBAL CONFERENCE ON COMPUTER SCIENCE, SOFTWARE, NETWORKS AND ENGINEERING, Istanbul Aydın University, Istanbul, Turkey, $19-21$ November 2015

[24] Amadou, D., Abdellah, A., \& Mohamed, E. "The Choice of the Best Proposal in Tendering with AHP Method: Case of Procurement of IT Master Plan's Realization", I.J. Information Technology and Computer Science, 2015, $12,1-11$

\section{Authors' Profiles}

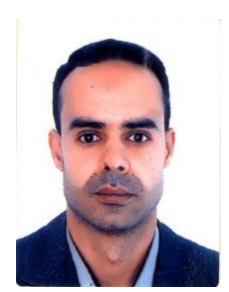

Essaid EL HAJI is a Ph.D student in LIST Laboratory at Abdelmalek Essaadi University. His current research interest includes artificial intelligence methods and techniques in educational and career guidance. He is a Teacher of computer science at the Chaabane High School in Larache-Morocco. He has several papers in International Conferences and Journals

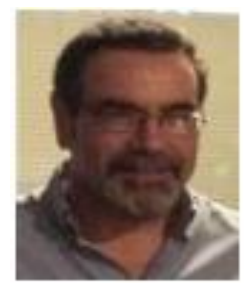

Abdellah AZMANI received his Ph.D. in Industrial Computing at the University of Science and Technology of Lille in 1991. $\mathrm{He}$ worked as a professor at the Ecole Centrale de Lille and at the Institute of Computer and Industrial Engineering from Lens. He is a member of the Laboratory of Automatics and Informatics of Lille (LAIL). He is a professor at Faculty of Sciences and Technology of Tangier, Morocco. He has contributed to many 
scientific research projects and he elaborates and produces many IT solution for learning games, eLearning, Public Administration, business management, good governance and decision support.

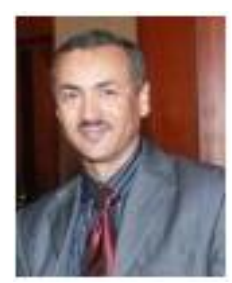

Mohamed EL HARZLI received his state doctorate in Instrumentation at Faculty of Science of Meknes (Morocco), after his Ph.D from the University of Lille (France) in Electronics. He is a professor at Faculty of Sciences and Technology of Tangier, Morocco. He received recently his Master in "Intellectual Property Rights" set up by the World Intellectual Property Organization (WIPO) and the African Intellectual Property Organization (OAPI)

How to cite this paper: Essaid EL HAJI, Abdellah Azmani, Mohamed El Harzli,"Using AHP Method for Educational and Vocational Guidance", International Journal of Information Technology and Computer Science(IJITCS), Vol.9, No.1, pp.917, 2017. DOI: $10.5815 /$ ijitcs.2017.01.02 